\title{
REZULTATI VIŠEGODIŠNJEG PRAĆENJA SALMONELOZNIH INFEKCIJA U FEDERACIJI BOSNE I HERCEGOVINE
}

\author{
Anesa Mešić ${ }^{1}$, Ivo Curićn ${ }^{2}$, Mateja Briševac ${ }^{3}$ \\ ${ }^{1}$ Studij sanitarnog inženjerstva, Fakultet zdravstvenih studija,Sveučilište u Mostaru \\ ${ }^{2}$ Fakultet zdravstvenih studija, Sveučilište u Mostaru \\ ${ }^{3}$ Klinika za ženske bolesti i porode, KBC Zagreb \\ Rad je primljen 3.3.2016. \\ Rad je korigiran 16.3.2016. \\ Rad je prihvaćen 10.4.2016.
}

\section{SAŽETAK}

UVOD: Sve bolesti uzrokovane sa salmonelama nazivaju se salmoneloze, pa u širem smislu riječi tu spadaju i trbušni tifus i paratifus. Danas je uobičajeno i klinički prihvatljivo pod nazivom salmoneloze ubrojiti samo one bolesti koje su uzrokovane svim drugim salmonelama, bez trbušnog tifusa i paratifusa (salmoneloze u užem smislu riječi) $i$ iste su predmet ove studije. Danas su salmoneloze u stalnom porastu kako u zemljama s niskim bruto društvenim proizvodom tako i u visoko razvijenim zemljama.

CILJ: Istražiti pojavnost salmoneloza i najvulenrabilnije dobne skupine za akviriranje salmoneloza u Federaciji Bosne i Hercegovine u vremenskom razdoblju od tri godine.

METODE: Studija je epidemiološka retrospektivna analiza pojavnosti salmoneloza u vremenskom razdoblju od tri godine (1.1.2012. do 31.12.2014. godine). U studiju su uključeni svi registrirani bolesnici s područja F BiH kod kojih je dokazana salmonelozna etiologija.

REZULTATI: U istraživanom razdoblju na području $\mathrm{F} \mathrm{BiH} \mathrm{ukupno} \mathrm{je} \mathrm{registrirano} 787$ bolesnika sa salmonelozama. Po učestalosti su salmoneloze u F BiH bile na trećem mjestu među registriranim akutnim crijevnim zaraznim bolestima. $\mathrm{Za}$ salmonelozne infekcije najvulnerabilnije starosne skupine su djeca od 0-6 godina i odrasli od 25-49 godina. Statistički značajno veća stopa obolijevanja zabilježena je u Sarajevskoj županiji u odnosu na HNŽ ( $\chi^{2}=273,542$; d.f.5; $\left.p<0,001\right)$, dok u Posavskoj i Bosansko-podrinjskoj županiji, začuđujuće, nije zabilježen niti jedan slučaj ovog morbidnog entiteta. U ispitivanom trogodišnjem razdoblju zabilježene su tri epidemije uzrovane s malim salmonelama. Među osobama oboljelim od malih salmonela nije registriran niti jedan smrtni slučaj.

Ključne riječi: salmonelozne infekcije, Federacija Bosne i Hercegovine

Osoba za razmjenu informacija:

Doc. dr. Ivo Curić

snjezanacu@yahoo.com

\section{UVOD}

Klinička skupina akutnih crijevnih zaraznih bolesti (ACZB), među koje spadaju i salmonelozne infekcije, danas predstavlja globalni javnozdravstveni problem budući na njih otpada oko $20 \%$ svih registriranih zaraznih bolesti. Poslije akutnih respiratornih bolesti to su najčešće registrirane akutne zarazne bolesti. Danas se smatra da u svijetu godišnje oboli otprilike 1 milijarda ljudi od ovih bolesti, a da čak 5 milijuna djece u dobi do 5 godina godišnje umire od ovog kliničkog sindroma (1-9). ACZB obuhvaćene su šiframa od A00 do A09 u Međunarodnoj klasifikaciji bolesti i srodnih zdravstvenih stanja-Deseta revizija.

Za ACZB karakteristična je fekalno-oralna transmisija kod koje uzročnik ili njegovi produkti ulaze u organizam kroz usta, razmnožavaju se u crijevu i najčešće se izlučuju stolicom. To i jest njihova najvažnija epidemiološka karakteristika, ali se ne može prihvatiti kao sveobuhvatna odrednica (1-6). Važno je naglasiti da kod nekih bolesti iz ove skupine, kao 
što su stafilokokno i klostridijsko trovanje hranom, nema fekalno-oralne transmisije. Treba naglasiti da je kod ovih bolesti inkubacija kratka i da se bolest može prezentirati i epidemijskom pojavom (1,3-9).

Među ACZB posebno mjesto zauzimaju salmonelozne infekcije koje su prouzročene gram negativnim štapićastim nesporogenim bakterijama koje pripadaju porodici Enterobacteriaceae. Salmonelozne infekcije se dijele na salmoneloze u širem i užem smislu riječi. Salmoneloze u širem smislu riječi obuhvaćaju sve bolesti prouzročene salmonelama, uključujući trbušni tifus i paratifus. Kako se uzročnici trbušnog tifusa i paratifusa (Salmonella typhi i Salmonella paratyphi) razlikuju se po svojim biološkim svojstvima od svih drugih salmonela, tako se i trbušni tifus i paratifus razlikuju po svojoj kliničkoj slici od bolesti izazvanih svim drugim tzv. „malim“ salmonelama. Zato se obično pod nazivom salmoneloze ubrajaju samo one bolesti uzrokovane tzv. drugim salmonelama, bez trbušnog tifusa i paratifusa (salmoneloze u užem smislu riječi, netifusne salmoneloze), i iste su predmet ovog rada (1-10). Salmonelozne infekcije obuhvaćene su prema Međunarodnoj klasifikaciji bolesti i srodnih zdravstvenih stanja u njenoj desetoj reviziji šifrom A02.

Danas su salmoneloze $\mathrm{u}$ stalnom porastu kako $\mathrm{u}$ zemljama s niskim bruto društvenim proizvodom tako i u visoko razvijem zemljama zbog sve proširenije industrijske obradbe namirnica, masovne društvene prehrane i čestih putovanja. Pojavljuju se sporadično i u većim ili manjim epidemijama.Salmoneloze ipak prevladavaju u područjima s lošim socijalno-ekonomskim životnim uvjetima i uvjetima gdje su higijenske navike na niskoj razini. Češće su u ljetnim mjesecima kad uzročnici mogu preživjeti u vanjskoj sredini (1-8,11-15).

Salmonele su paraziti ljudi, domaćih i divljih životinja, te uzrokuju bolesti iz grupe zoonoza (1-8,1115). U hranu salmonele mogu dospjeti iz namirnica od kojih se hrana priprema, ali i preko ruku osoba koje učestvuju u pripremi živežnih namirnica. Najčešći su izvor infekcije jaja i meso peradi koja nisu dovoljno termički obrađena. Kao čest izvor infekcije navode se sladoledi i razne kreme napravljene od sirovih jaja, a posebno majoneza. Salmonele su vrlo otporne na štetne utjecaje okoline, te mogu jako dugo preživjeti izvan organizma domaćina, u vodi i zemlji kamo dolaze životinjskim ili ljudskim izmetom (11-15). Prema antigenskoj strukturi salmonele se dijele u deset osnovnih skupina koje obuhvaćaju više od 4.200 vrsta i tipova. Mnoge salmonele su karakteristične za određeno podneblje, ali ima i kozmopolitskih tipova (1-9).

Salmonele su izuzetno invazivne bakterije, koje nakon što uđu u organizam domaćina preko probavnog sustava, mogu prodrijeti u površinske stanice tankog i debelog crijeva. Ponekad ulaze u krv i tada mogu doći do različitih organa, u kojima stvaraju upale. Neki tipovi salmonela nakon prodora kroz epitelne stanice crijeva budu fagocitirane od leukocita, što im omogućava dugogodišnje preživljavanje u makroorganizmu bez popratnih simptoma i znakova bolesti domaćina koji može povremeno ili trajno izlučivati salmonele u stolici (kliconoštvo) (1-6).

Infekcija sa salmonelama može biti subklinčka ili klinički manifestna kada se prezentira kao akutni gastroenteritis, paratifus ili salmonela vrućica i septički sindrom (1-8,11-15).Akutni gastroenteritis ili otrovanje hranom prouzročeno salmonelama najčešći je, ali i klinički najblaži oblik salmoneloza (1,8,11-15).Nakon inkubacije od 1 do 2 dana, bolest počinje naglo, visokom temperaturom, bolovima $\mathrm{u}$ trbuhu, mučninom, povraćanjem i učestalim vodenastim stolicama koje su bezbojne do žutozelene, smrdljive, a vrlo rijetko sluzavo-krvave. Pored ovih gastrointestinalnih simptoma, prisutni su uz temperaturu i drugi opći simptomi kao što su glavobolja, bolovi u mišićima i zglobovima. Nakon 2 do 5 dana temperatura pada na normalnu, bolovi u trbuhu kao i povraćanje prestaju. Broj stolica se smanjuje, one postaju kašaste i konačno formirane. Ovakva klinička slika bolesti posljedica je infektivno-toksičnog djelovanja salmonela u crijevima i gubitka vode i elektrolita. Salmonele obično ne prodiru u krvnu cirkulaciju i ne šire se u druge organe. U težem obliku bolesti nastupa dehidracija, koja je praćena suhoćom usta i sluznica, afonijom, grčevima u mišićima i znakovima šoka. Liječenje je simptomatsko, a u slučaju sumnje na bakterijemiju (u oko $5 \%$ slučajeva) 
daju se antibiotici: kotrimoksazol, konoloni ili treća generacija cefalosporina $(1,8,10-15)$.

Osim Salmonellae paratyphi A, Salmonellae paratyphi B i Salmonellae paratyphi C i svaka druga tzv. mala salmonela može izazvati salmonelu-vrućicu ili paratifus. Salmonela-vrućica se klinički prezentira samo s općim simptomima koji su odraz bakterijemije. Sliči blagom trbušnom tifusu s rijetko prisutnim komplikacijama. Vrućica je remitentnog tipa, redovito je praćena tresavicama i obično traje dulje od 5 dana. Od salmonela-vrućice rijetko obolijevaju prethodno zdravi, mladi ljudi. To je u prvom redu bolest dojenčadi, male djece, starijih ljudi i imunokompromitiranih bolesnika (1-8,10-15).Liječenje je simptomatsko i obvezatno gore navedeni antibiotici (1-8,10-15). Prognozabolesti je dosta dobra, a kod male djeca i staraca mogući su i smrtni ishodi (3-7).

Septikemija je najrjeđi ali zato najteži klinički oblik salmoneloza. Najčešće se pojavljuje u osoba koje nisu u stanju lokalizirati infekciju, a to su: dojenčad i mala djeca kao i starije i imunokompromitirane osobe.Bolest počinje naglo, visokom temperaturom s treskavicom, općom slabošću, hipotenzijom, zatajenjem bubrega i drugim simptomima. Ubrzo se jave i simptomi septičkih metastaza, a klinička slika i težina bolesti zavisi od lokalizacija metastaza. Septičke metastaze su najčešće lokalizirane u: plućima, pleuri, moždanim ovojnicama, žučnom mjehuru, bubrezima, srčanim zaliscima, perikardu, kostima, zglobovima, testisu i epididimisu. U terapiji su obvezatni antibiotici uz potentnu simptomatsku terapiju (1-8,10-15).

Dijagnoza salmoneloza postavlja se na osnovu kliničke slike, laboratorijskih nalaza, epidemioloških podataka i dokaza salmonele u stolici i/ili krvi. Za etiološku dijagnozu salmonela-sepse poželjno je izolirati uzročnika iz krvi ili sekundarnih žarišta (1$8)$.

Mjere kojima se može spriječiti nastanak i širenje salmoneloznih infekcija su: zdravstveni odgoj pučanstva o važnosti opće i sanitarne higijene, permanentni sanitarno-veterinarski nadzor nad namirnicama životinjskog i biljnog podrijetla (u proizvodnji, preradi, transportu i distribuciji),kontinuirani zdravstveni nadzor nad vodoopskrbom pučanstva, medicinski nadzor nad korektnim rješavanjem otpadnih tvari i fekalija, sveobuhvatna i permanentna kontrolakliconoštva(otkrivanje, nadzor i edukacija). Temeljna mjera u prevenciji salmoneloza je redovito pranje ruku prije svakog rukovanja i konzumiranja živežnih namirnica kao i pranje ruku prije i poslije obavljanja fizioloških potreba (1-4,9,11-15).

\section{CILJ STUDIJE}

Prikupiti i analizirati podatke o incidenciji bolesnika s ACZB i salmoneloznim infekcijama u Federaciji $\mathrm{BiH}$ kao i u pojedinim njenim županijama u trogodišnjem vremenskom razdoblju (od 1.1.2012. do 31.12.2014. godine). Posebno je analizirana struktura morbiditeta ACZB kao i dobna struktura najvulenrabilnijih starosnih skupina za akviriranje salmoneloza.

\section{ISPITANICI I POSTUPCI}

Analizirani uzorak čine svi registrirani bolesnici od kliničkog sindroma ACZB i salmoneloza infekcija na području $\mathrm{F} \mathrm{BiH}$. U analizu su također uključeni i svi oboljeli od navedenih bolesti u pojedinim županijama F BiH.

Ukupna površina u F BiH iznosi $26.110 \mathrm{~km}^{2}$. U analiziranom razdoblju u deset županija F BiH živjelo je 2,371.603 stanovnika, odnosno u: Hercegovačko-neretvanskoj 236.278; Unsko-sanskoj 299.343; Posavskoj 48.089; Tuzlanskoj 477.278; Zeničko-dobojskoj 385.067; Bosansko-podrinjskoj 25.336; Središnje-bosanskoj 273.149; Sarajevskoj 438.443; Zapadno-hercegovačkoj 97.893 i Hercegbosanskoj 90.729. U promatranom trogodišnjem razdoblju u F BiH od ACZB ukupno je oboljelo 14.496 osoba. $\mathrm{U}$ istom je razdoblju od salmoneloza oboljelo 787 osoba.

Podaci o broju stanovnika, dobnoj zastupljenosti bolesnika oboljelih od opserviranih bolesti na istraživanom području dobiveni su iz Zdravstvenog statističkog godišnjaka $\mathrm{F}$ BiH Zavoda za javno zdravstvo F BiH iz Sarajeva i epidemioloških biltena (16-18).

Provedeno je opservacijsko retrospektivno istraživanje u koje su uključeni podaci o oboljelim 
osobama od sindroma ACZB i salmoneloza u analiziranom području kroz trogodišnje razdoblje od 1.1.2012. do 31.12.2014. godine. Istraživanje je provedeno u Federalnom zavodu za javno zdravstvo u Mostaru.

Parametri istraživanja bili su incidencija obolijevanja od ACZB i salmoneloza (ukupna i po pojedinim godinama) kao i incidencija obolijevanja od najčešćih bolesti iz ovog kliničkog sindroma u istraživanom području. Demografski i epidemiološki podaci o bolesnicima uneseni su u datoteku koja je kreirana za potrebe ovog istraživanja.

\section{STATISTIČKA ANALIZA}

Stopa morbiditeta ACZB i salmoneloznih infekcija na istraživanim područjima izračunata je po formuli (19):

\section{$\frac{\text { broj novooboljelih u odredenom vremenskom razdoblju }}{\text { broj stanovnika na istraživanom prostoru }} \times 100.000$}

Od statističkih testova uključenih u SPSS paket, korišteni su: kumulativna incidencija za prikaz novooboljelih slučajeva bolesti i hi kvadrat test kao statistički test za testiranje nul-hipoteze. Kao razina značajnosti uzeta je vrijednost $\mathrm{p}<0,001$ (19).

Za statističku analizu korišten je programski sustav SPSS for Windows (inačica 13.0, SPSS Inc, Chicago, Illinois, SAD) i Microsoft Excell (inačica 11. Microsoft Corporation, Redmond, WA, SAD).

\section{REZULTATI}

Kretanje morbiditeta ACZB po godinama u Federaciji $\mathrm{BiH}$ u razdoblju od 1.1.2012. do 31.12.2014. godine prikazuje slika 1 .

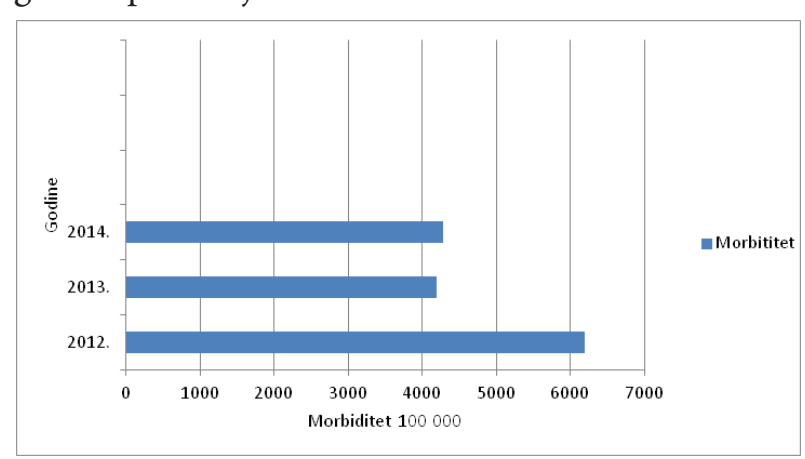

Slika 1. Morbiditet/100.000 akutnih crijevnih zaraznih bolesti u Federaciji Bosne i Hercegovine u razdoblju od 1.1.2012. do 31.12.2014. godine
$\mathrm{U}$ ispitivanom trogodišnjem razdoblju u Federaciji $\mathrm{BiH}$ od $\mathrm{ACZB}$ ukupno je registrirano 14.668 osoba, pa su ove bolesti po učestalosti na drugom mjestu, odmah poslije respiratornih zaraznih bolesti. Tako je u 2012. godini, na području Federacije BiH bilo registrirano 6.195 oboljelih od ACZB uz incidenciju 261,22 na 100.000. U 2013. godini na području Federacije BiH registrirano je 4.196 oboljelih osoba od tih bolesti uz registriranu incidenciju obolijevanja od 176,93 na 100.000 . Tijekom posljednje istraživačke godine registrirano je 4.277 oboljelih od ACZB uz stopu morbiditeta 180,34 na 100.000 .

Podaci o strukturi morbiditeta u kliničkom sindromu ACZB prikazani su u slici 2. iz koje je vidljivo je da su najčešće ACZB u Federaciji BIH, u promatranom razdoblju bile akutni enterokolitis, salmoneloze i alimentarne toksoinfekcije.

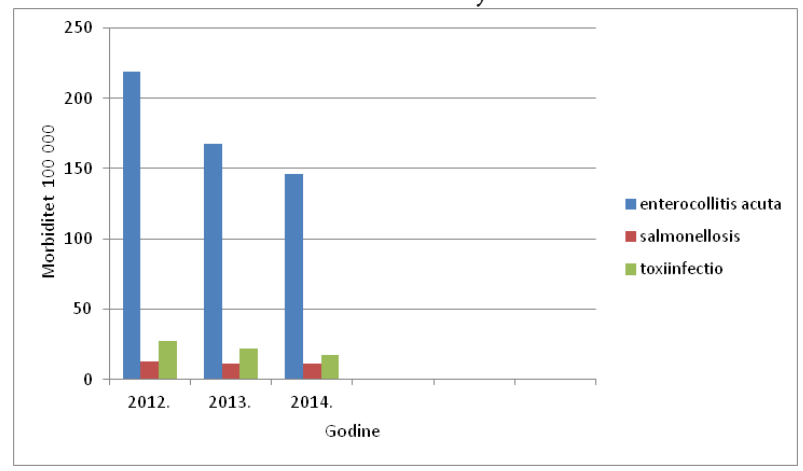

Slika 2. Morbiditet/100.000 najčešćih akutnih crijevnih zaraznih bolesti u Federaciji Bosne i Hercegovine u razdoblju od 1.1.2012. do 31.12.2014. godine

$\mathrm{U}$ istraživanom razdoblju na području $\mathrm{F} \mathrm{BiH}$ ukupno je registrirano 787 osoba sa salmonelozama (Slika 3). Najveći broj tih bolesnika zabilježen je na području Sarajevske $(\mathrm{n}=415)$, potom Zeničko-dobojske ( $\mathrm{n}=91)$, HNŽ $(\mathrm{n}=88)$, Herceg-bosanske ( $\mathrm{n}=64)$, Tuzlanske $(\mathrm{n}=46)$ i Unsko-sanske županije $(\mathrm{n}=44)$. Najmanji broj registriranih bolesnika, zapažen je u Zapadno-hercegovačkoj $(n=14)$ i Srednje-bosanskoj županiji ( $\mathrm{n}=25)$. U istom razdoblju u Posavskoj i Bosansko-podrinjskoj županiji nije registriran niti jedan bolesnik sa salmoneloznom infekcijom. Valja naglasiti da je najveći broj salmoneloza u tijeku jedne kalendarske godine također zapažen u Sarajevskoj županiji. Tada su u 2012. godini registrirana 192 bolesnika. 


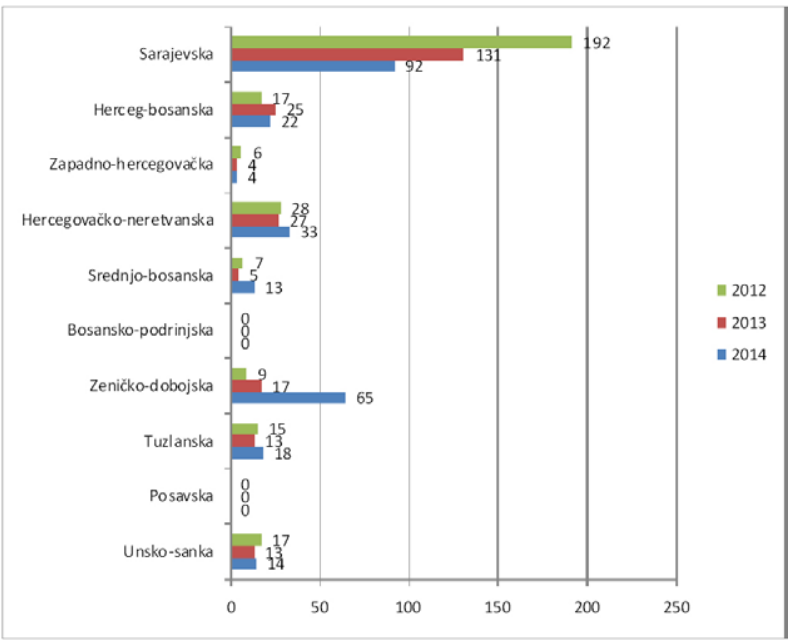

Slika 3. Zastupljenost salmoneloza po županijama u Federaciji Bosne i Hercegovine u razdoblju od 1.1.2012. do 31.12.2014. godine

Slika 4. razvidno pokazuje da postoji statistički značajno veća stopa obolijevanja od salmoneloznih infekcija u Federaciji BiH u odnosu na istu u HNŽ $\left(\chi^{2}=483.319 ;\right.$ d.f.5; $\left.\mathrm{p}<0,001\right)$.

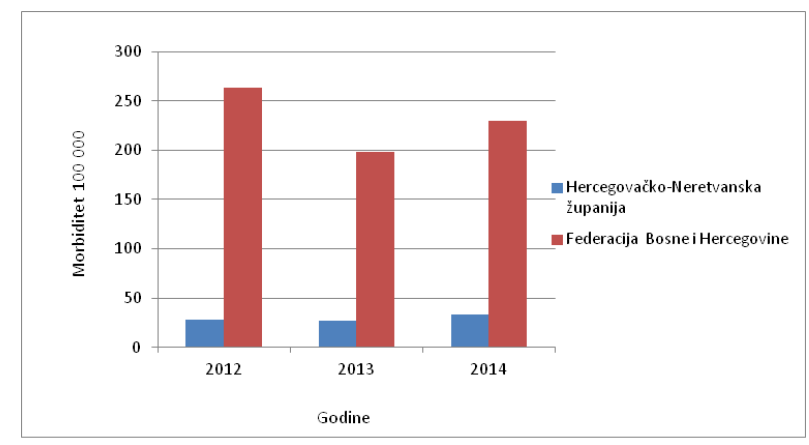

Slika 4. Usporedba morbiditeta/100.000 salmoneloza u Federaciji Bosne i Hercegovine i Hercegovačko-neretvanskoj županiji u razdoblju od 1.1.2012. do 31.12.2014. godine

Kretanje morbiditeta od salmoneloza u Sarajevskoj županji i HNŽ prikazuje slika 5, iz koje je vidljivo da je najveći broj oboljelih u obje županije registriran 2012., potom 2013., dok je najmanji broj oboljelih registriran u 2014. godini. Iz iste slike je razvidno da postoji statistički značajno veća stopa oboljenja od ovih infekcija u Sarajevskoj u odnosu na HNŽ $\left(\chi^{2}=273,542\right.$; d.f.5; $\left.p<0,001\right)$.

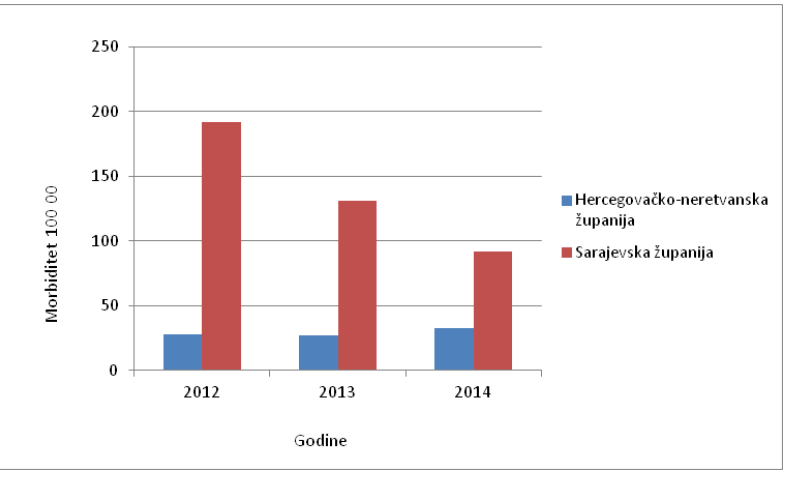

Slika 5. Usporedba morbiditeta/100.000 salmoneloza u Hercegovačko-neretvanskoj i Sarajevskoj županiji u razdoblju od 1.1.2012 do 31.12.2014. godine

$\mathrm{U}$ ispitivanom trogodišnjem razdoblju u Posavskoj županiji, kako je prikazano na slici 6 . nije registrirana niti jedna salmonelozna infekcija i postoji statistički značajno veća stopa obolijevanja od ovih bolesti u Tuzlanskoj u odnosu na Posavsku županiju $\left(\chi^{2}=25,274 ;\right.$ d.f. $\left.2 ; \mathrm{p}<0,001\right)$.

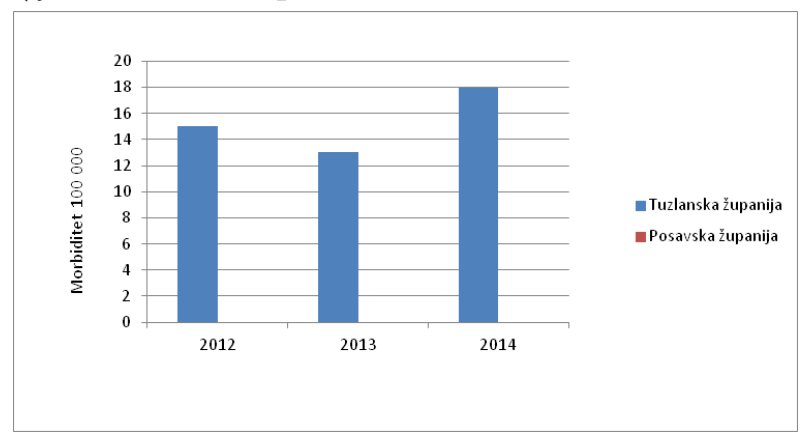

Slika 6. Usporedba morbiditeta/100.000 salmoneloza u Tuzlanskoj i Posavskoj županiji u razdoblju od 1.1.2012. do 31.12.2014. godine

Usporedba morbiditeta od salmoneloznih infekcija u Tuzlanskoj i HNŽ prikazana je na slici 7, iz koje je vidljivo da postoji statistički značajno veća stopa obolijevanja u HNŽ u odnosu na kompariranu županiju $\left(\chi^{2}=14,675 ;\right.$ d.f.5; $\left.p<0,001\right)$.

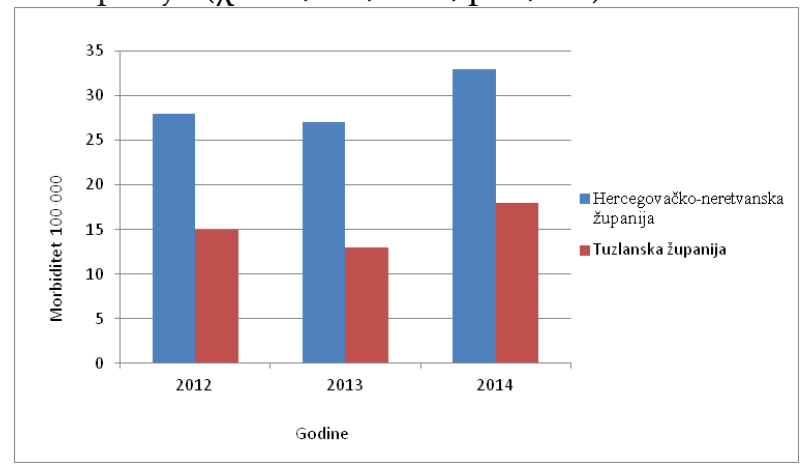

Slika 7. Usporedba morbiditeta/100000 salmoneloza u Hercegovačko-neretvanskoj i Tuzlanskoj županiji u razdoblju od 1.1.2012. do 31.12.2014. godine. 
Iz tablice 1. koja prikazuje udio salmoneloznih infekcija u strukturi morbiditeta ACZB u razdoblju 2012-2014. godine, vidljivo je da su salmonelozne infekcije bile najviše zastupljene 2014. godine (6,08 \%).

Tablica 1: Broj registriranih salmonelozas brojem epidemija i najvulnerabilnijim dobnim skupine za dobivanje ovih bolesti u Federaciji Bosne i Hercegovine, razdoblje od 1.1.2012. do 31.12.2014. godine

\begin{tabular}{ccccc}
\hline Godina & $\begin{array}{c}\text { Broj } \\
\text { registriranih } \\
\text { Salmoneloza }\end{array}$ & $\begin{array}{c}\text { Udio salmoneloznih } \\
\text { infekcija u ukupnom } \\
\text { broju ACZB (\%) }\end{array}$ & $\begin{array}{c}\text { Najugroženija } \\
\text { starosna skupina } \\
\text { (\%) za dobivanje } \\
\text { salmoneloza }\end{array}$ & $\begin{array}{c}\text { Broj } \\
\text { epidemija } \\
\text { uzrokovanih } \\
\text { salmonelama }\end{array}$ \\
\hline 2012. & 291 & 4,69 & 0-6 god. (32,64) & 2 \\
2013. & 225 & 5,32 & 25-49 god. (30,27) & 0 \\
2014. & 261 & 6,08 & 0-6 god. (26,60) & 1 \\
\hline
\end{tabular}

Iz iste tablice razvidno je da su djeca od 0-6 godina i odrasle osobe u dobi od 25-49 godina najvulnerabilnije starosne skupine za akviriranje salmonelozne infekcije. $U$ istraživanom razdoblju desile su se 3 epidemije ACZB, i to dvije 2012. i jedna 2014. godine (Tablica 1).

\section{RASPRAVA}

Poslije akutnih respiratornih zaraznih bolesti, ACZB su najčešće akutne zarazne bolesti na koje otpada približno $20 \%$ svih registriranih zaraznih bolesti. Prezentiraju se kao jedinstven klinički sindrom kod kojih uzročnik ili njegovi produkti ulaze u organizam kroz usta, razmnožavaju se u crijevu i najčešće se izlučuju iz organizma stolicom (1-9).

$\mathrm{U}$ istraživanom području ACZB i salmoneloze imaju obilježja endemo-epidemijske rasprostranjenosti i predstavljaju važan zdravstveni i socijalno-gospodarski problem (1-5,9). Prava incidencija ovih bolesti u nas, kao i diljem svijeta, nije poznata, jer lakši bolesnici ne traže liječničku pomoć (9). Isto tako, moramo biti svjesni činjenice da se zarazne bolesti, u načelu, pa tako i ACZB na istraživanom području ne prijavljuju redovito i savjesno, pa postoje i propusti u registraciji istih $(9,20)$. Koliko se doista bolesnika s ACZB i salmonelozama ne prijavi medicinskoj službi, odnosno koliki je postotak obuhvata prijavljivanja, može se samo naslućivati (20). Ipak, može se zaključiti da je broj oboljelih od ACZB na istraživanom području, kao i diljem svijeta, mnogo veći nego što pokazuju službeni statistički pokazatelji $(3,9,20)$.

Rezultati ovog istraživanja pokazuju, sukladno podacima iz literature, da su najčešće ACZB u F BiH i opserviranim županijama akutni enterokolitis, salmoneloze i alimentarne toksoinfekcije (1-6,16$18,20)$.

Salmoneloze u širem smislu riječi jesu sve bolesti uzrokovane salmonelama, uključujući i trbušni tifus. Salmonelozne infekcije u užem smislu riječi su bolesti koje uzrokuju druge tzv. „male salmonele“, koje su poglavito paraziti životinja i koje se prenose na čovjeka uglavnomnamirnicama životinjskog podrijetla te kao takve spadaju u zoonoze. U stalnom su porastu zbog sve proširenije industrijske obradbe namirnica, porasta masovne društvene prehrane i češćih egzotična putovanja u endemska područja salmoneloznih infekcija. Zato su one danas globalni javno-zdravstveni problem i predstavljaju vrlo važan problem kliničke medicine i javnoga zdravstva (1-9,11-15,20).

Provedeno je istraživanje pokazalo statistički značajne razlike $\mathrm{u}$ incidenciji salmoneloznih infekcija na pojedinim područjima $\mathrm{F} \mathrm{BiH} \mathrm{(16-18).} \mathrm{Neshvat-}$ ljivo je da u Posavskoj i Bosansko-podrinjskoj županiji $u$ istraživanom trogodišnjem razdoblju nije registrirana niti jedna osoba oboljela od salmoneloza. Isto tako teško je prihvatiti da je u istom vremenskom razdoblju u Zapadno-hercegovačkoj županiji registrirano samo 14 ili 25 bolesnika u Srednje-bosanskoj županiji. Može li se ova razlika u stopi obolijevanja shvatiti različitim epidemiološkim čimbenicima, teško je dati egzaktan i korektan odgovor. Bliži smo mišljenju, koje je sukladno mišljenjima iz literature, da na istraživanom području ne postoje takvi epidemiološki parametri koji bi mogli signifikantnije utjecati na incidenciju ovih bolesti (1$4,9,11,20)$. Potporu našim razmišljanjima nalazimo u epidemiološkim biltenima Zavoda za javno zdravstvo F BiH, kao i u stručnoj literaturi koja obrađuje ovu problematiku i gdje je eksplicitno navedeno da je primjetno nizak stupanj prijavljivanja i nadzora nad zaraznim bolestima, a sto u konačnici daje nerealnu sliku učestalosti ovih bolesti $(16-18,20)$. 
Uvidom u epidemiološke biltene Zavoda za javno zdravstvo F BiH primjetan je najveći broj salmoneloznih infekcija u 2012.godini kada su registrirane i dvije epidemije u Sarajevskoj županiji. U istom razdoblju primjetna je i najveća stopa morbiditeta od264,98 na 100.000 (16-18).

Rezultati ovog istraživanja pokazuju statistički značajno veću stopu obolijevanja od salmoneloza u F BiH i Sarajevskoj županiji u odnosu na istu stopu u HNŽ kao i HNŽ u odnosu na Tuzlansko-podrinjsku županiju, što smatramo posljedicom različitog pristupa i nadzora nad zaraznim bolestima $(16-18,20)$.

Podaci dobiveni u ovom istraživanju pokazuju, sukladno podacima iz literature, da su za salmoneloze najvulnerabilnije starosne skupine djeca od 0-6 godina i odrasli u dobi od 25-49 godina. Smatramo da su djeca u navedenoj starosnoj skupini sklonija salmoneloznim infekcijama zbog nedovoljno razvijene nespecifične obrane organizma i neadekvatnog imunološkog sustava kao i nedovoljno formiranih higijenskih navika. Isto tako mislimo da je starosna skupina od 25-49 godina sklona ACZB zbog načina života i povećane ekspozicije tim bolestima (1-8,1113,16-18,20).

U promatranom razdoblju registrirane su tri epidemije uzrokovane s malim salmonelama kod osoba koje su u svatovima konzumirale uglavnom živežne namirnice od kontaminiranih jaja-majoneza. Navedene epidemije dogodile su se u Sarajevskoj (dvije) i jedna u Zeničko-dobojskoj županiji $(16,18)$.

Postavlja se pitanje kako imati pravi uvid u broj oboljelih od zaraznih bolesti pa tako i uvid u stanje ACZB i salmoneloza. Da bi se stekao pravi uvid u incidenciju tih bolesti mišljenja smo da je potrebno formirati odgovarajuću bazu podataka u županijskim i u Federalnom zavodu za javno zdravstvo. Kako to postići? Smatramo da bi sve zdravstvene ustanove trebale mnogo ažurnije izvještavati svoje županijske zavode za javno zdravstvo koji bi potom sustavom subordinacije izvještavale Federalni zavod za javno zdravstvo, a što bi u konačnici dalo bolju bazu za poduzimanje raznih pravovremenih preventivnih aktivnosti $(2,3,9,11-13,20)$.

\section{ZAKLJUČAK}

ACZB i salmoneloze su globalan javno-zdravstveni problem i zauzimaju značajno mjesto u strukturi morbiditeta svih zemalja svijeta. U promatranom trogodišnjem razdoblju ACZB su u Federaciji $\mathrm{BiH}$ i analiziranim županijama bile po učestalosti na drugom mjestu, dok su salmoneloze u strukturi morbiditeta ACZB zauzimale treće mjesto. Ovo je istraživanje pokazalo da su najugroženije starosne skupine za ACZB djeca od 0-6 godina, te odrasli u starosnoj dobi od 25 do 49 godina. $U$ istraživanom razdoblju nisu zabilježeni smrtni ishodi zbog ACZB i salmoneloznih infekcija. Provedeno je istraživanje pokazalo statistički značajne razlike u incidenciji ACZB i salmoneloznih infekcija na pojedinim područjima F BiH, što se ne može se shvatiti kao posljedica različitih epidemioloških čimbenika, već kao najvjerojatniji pokazatelj neučinkovitog sustava prijavljivanja i nadzora nad zaraznim bolestima. $\mathrm{Da}$ bi se stekao pravi uvid u zarazne, pa tako i ACZB potrebno je formirati odgovarajuću bazu podataka kako u županijskim zavodima za javno zdravstvo te konsekutivno tome i u Federalnom zavodu za javno zdravstvo. Da bi se to postiglo sve bi zdravstvene ustanove trebale mnogo ažurnije izvještavati svoje županijske zavode za javno zdravstvo koji bi potom sustavom subordinacije izvještavali Federalni zavod za javno zdravstvo. To bi u konačnici dalo bolju bazu za poduzimanje raznih pravovremenih preventivnih aktivnosti i stvorilo bi mogućnost kompariranja $s$ razvijenim zdravstvenim sustavima.

\section{LITERATURA}

1. Kuzman I, ur. Infektologija za visoke zdravstvene škole. Zagreb: Medicinska naklada; 2012.

2. Pinjo F. Crijevne zarazne bolesti. U: Krkić-Sautović S, ur. Infektologija. Sarajevo: Medicinski fakultet Sarajevo i Asocijacija infektologa u Bosni Hercegovini, Sarajevo-Tuzla; 2011.

3. Bakašun V. Bolesti koje se prenose preko probavnog sustava. U: Ropac D, ur. Epidemiologija zaraznih bolesti. Zagreb: Medicinska naklada; 2006. 
4. Breitenfeld V, Beus A, Desnica B. Gastrointestinalne infekcije. U: Begovac J, ur. Infektologija 1. izd. Zagreb: Profil; 2011.

5. Liesla WP, Guerant RL. Infectious diarrhea. U: Wilson RW, ur. Current Diagnosis \& Treatment in Infectious Diseases. Rochester: Mc Graw Hill Companies; 2011.

6. Ilnyckyj A. Clinical evaluation and managment of acute infectious diarrhea in adults. Gastroenterol Clin North Am. 2010;30:599-609.

7. Souhwick FS: ur. Gastrointestinal and Hepatobiliay Infections. New York-Toronto: McGraw-Hi11; 2003.

8. Obad A, Curić I, Tomak-Marković J. Rezultati višegodišnjeg praćenja akutnih crijevnih zaraznih bolesti u Hercegovačko-neretvanskoj i Dubrovačkoj županiji. Zdravstveni glasnik 2015;1:73-9.

9. Aleraj B. Globalna epidemiologija zaraznih bolesti.Infektološki glasnik. 2007;23-6.

10. Schonwald S, Baršić B, ur. Priručnik za liječenje i sprečavanje infektivnih bolesti. Zagreb: Birotisak-Zagreb; 2001.

11. Wikipedia. [Internet] Dostupno: http://hr.wikipedia.org/wiki/Crijevne_zarazne_bolesti; pristupljeno 21.7.2015.

12. Vaše zdravlje. [Internet] Dostupno: http://www. vasezdravlje.com/izdanje/clanak/420/ pristupljeno 21.7.2015.
13. Nastavni Zavod za javno zdravstvo Primorsko-goranske županije [Internet]. http://www. zzjzpgz.hr/odjeli/prevovis/Rizik-11.pdf; pristupljeno 21.7.2015.

14.www.centar-zdravlja.net. Crijevne-zarazne-bolesti. [Internet] Dostupno: http://www. centar-zdravlja.net/bolesti/162/crijevne-zarazne-bolesti- općenito/klinička-slika/3. pristupljeno 15.6.2015.

15.www.leko-grbic.hr [Internet] Dostupno: http:// www.leko-grbic.hr/hrv/edukacija =crijevnebolesti.html; pristupljeno 15.6.2015.

16.Zavod za javno zdravstvo Federacije BiH. Zdravstveno statistički godišnjak Federacije Bosne i Hercegovine za 2012. godinu. Sarajevo; 2013.

17.Zavod za javno zdravstvo Federacije BiH. Zdravstveno statistički godišnjak Federacije Bosne i Hercegovine za 2013.godinu. Sarajevo; 2014.

18. Zavod za javno zdravstvo Federacije BiH. Zdravstveno statistički godišnjak Federacije Bosne i Hercegovine za 2014. godinu. Sarajevo; 2015.

19. Babuš V. Epidemiološke metode. Zagreb: Medicinska naklada; 2000.

20. Ravlija J. Nadzor nad zaraznim oboljenjima. U: Vasilj I, ur. Opća epidemiologija. Mostar: Fram Ziral; 2014. 


\title{
THE RESULTS OF A LONG TERM RESEARCH OF SALMONELLA INFECTIONS IN THE FEDERATION OF BOSNIA AND HERZEGOVINA
}

\author{
Anesa Mešić ${ }^{1}$, Ivo Curić2 ${ }^{2}$ Mateja Briševac ${ }^{3}$ \\ ${ }^{1}$ Sanitary engineering, Faculty of Health Sciences, University of Mostar \\ ${ }^{2}$ Clinic for Obstetrics and Gynecology, Clinical Hospital Center Zagreb \\ ${ }^{3}$ Faculty of Health Sciences, University of Mostar
}

\begin{abstract}
INTRODUCTION: All infections are caused by the salmonella bacteria are called salmonellosis, so in the wider sense these infections include the typhoid and paratyphoid. Today it is common and clinically acceptable to consider under the name of salmonellosis only those diseases that are caused by all other salmonella, without the typhoid and paratyphoid (salmonellosis in the strict sense of the word) and the same are the subject of this study. Today, salmonelloses are in constant growth both in countries with low GNP as well as in highly developed countries.

OBJECTIVE: To investigate the occurrence of salmonella and the most vulnerable age group for the evasion of salmonellosis in the Federation of Bosnia and Herzegovina in the period of three years.

METHODS: The study is an epidemiological retrospective analysis of the incidence of salmonella in the period of three years $(01 / 01 / 2012$ to 31/12/2014). The study included all registered patients in the Federation of Bosnia and Herzegovina who had salmonellosis.

RESULTS: In the research period of three years, there were 787 patients with salmonellosis registered in the Federation of Bosnia and Herzegovina. According to incidence, salmonelloses are on the third place among acute intestinal infectious diseases in the Federation of Bosnia and Herzegovina. For salmonella infections the most vulnerable age groups are children from 0 to 6 years old and adults from 25 to 49 years old. A significantly higher rate of disease rate was recorded in the Sarajevo Canton in relation to the Herzegovina-Neretva Canton $(\chi 2=273.542$; d.f.5; $\mathrm{p}<0.001)$, while in the Posavina and Bosnian-Podrinje Canton, surprisingly, not a single case of this morbid entity was recorded. In the three year study period three epidemics caused by salmonella were recorded, and not a single death caused by the same bacteria was recorded. Keywords: salmonella infection, the Federation of Bosnia and Herzegovina
\end{abstract}

